\title{
The man with big ears, and big dreams that took India to the moon*
}

\author{
Amrita Shah** \\ 1024, New Haven, Dasanapura Hobli, Off Tumkur Road, Near Golden Palms Hotel, Bengaluru 562123
}

On 12 August 1919, a baby boy was born in the home of Ahmedabad's leading textile mill-owner; his siblings looked at him and declared he had big ears, 'just like Gandhiji', which they wanted to fold like betel leaves. The baby was Vikram Sarabhai. Monday marks the birth centenary of this remarkable figure, even as Chandrayaan-2, steadily surging towards the moon shines a light on the Indian space programme which he founded.

Vikram's was a charmed life. Born in the lap of luxury, he went to an esoteric experimental school set up by his parents equipped with a workshop to nurture his scientific inclinations. At 18, he went to Cambridge with a recommendation from family friend Rabindranath Tagore. When World War Two intervened, he moved to the Indian Institute of Science in Bengaluru to continue his research under Nobel Laureate C. V. Raman. Here he was thrown into the company of a brilliant young scientist Homi Bhabha similarly stranded by the War and met classical dancer Mrinalini Swaminathan with whom he fell in love. 'Science is so similar to art...both spiritually aware of the indivisible wholeness of the cosmos... Vikram as a scientist and I as a dancer shared a "togetherness" that was hard to define,' Mrinalini would write.

When American physicist and Nobel Laureate Robert Millikan was in India to acquire data for his world survey of cosmic ray intensity, Vikram helped with his balloon experiments whetting his own interest in exploring cosmic rays and properties of the Upper Atmosphere. A decade and a half later, when scientists would see satellites as a viable tool to study space, Nehru and Bhabha would support the setting up of an Indian National Committee for Space Research with him as chairman.

This charmed life had its dark side. In his childhood, Vikram's aunt Anasuya, who had formed a labour union, brought home stories of the daily struggles of textile millworkers. The freedom movement came knocking, his mother and sister were jailed which made his younger sister Gita at least, 'desperately miserable'. A few years later Vikram's brother died from a sudden illness. It is likely that these experiences instilled in him a strong social conscience manifested in his determination to use sophisticated technology, particularly the space programme to improve the lives of India's poor. Perhaps they also engendered in him an acute awareness of life's transience which is one way to explain his prolific parallel career as a builder of institutions such as The Indian Institute of Management (IIM-A), the Darpana Academy of Performing Arts, and the National Institute of Design. He also ran successful businesses, was a visiting professor at Massachusetts Institute of Technology and piloted

*Source: 'The Times of India'.**Twitter: @amritareach the Atomic Energy Commission at a crucial stage after Bhabha's death.

But even while he engaged with multiple fields, Vikram remained at heart a scientist. Not just the practise of science or a particular area of research but the business of being a scientist and thinking like one shaped his approach. 'A person who has imbibed the ways of science injects into a situation a new way of looking at it', he said.

A 'new way of looking' and all that went with it innovation, enterprise and improvisation-were hallmarks of Vikram's modus operandi. The early days of the space programme, for instance, unfolded in the former fishing village of Thumba near Thiruvananthapuram, a stretch of wilderness with no infrastructure, cycles and rusty buses and an office in an old church building without even a roof to keep pigeons out. In these primitive conditions and with an absence of indigenous precedents, a team of young Indian scientists created bits of technology, propellants, nose cones and payloads from scratch.

Vikram's methods were tough, he could create competition on the one hand (one team called its propellant 'Mrinal' after his wife to curry favour), and encourage staffers to push with the 'thin edge of the wedge' on the other. 'We were in the air all the time, thinking big', says Vasant Gowarikar, who was working on explosives. 'The insistence on indigenization all the time was a great motivation.' In November 1963, the first blast-off took place and Vikram sent home a telegram: 'Gee whiz wonderful rocket shot'.

Vikram died unexpectedly in his sleep on 30 December 1971 at the age of 52. By this time, the space programme had swelled to a staff of thousands and he had worked out a blueprint for its future course both technologically and with applications in agriculture, forestry, oceanography, geology and cartography. In a brief life span, Vikram had contributed enormously to the shaping of modern India and he had done it with verve. Hobnobbing with the world's most distinguished one day, whistling and flipflopping in his chappals up the steps of his laboratory the next and always carrying his own briefcase to avoid getting into 'feudal habits'.

He was also, to use a word rarely applied to Indian achievers, a 'dreamer'. His daughter Mallika recalls how he was often lost in a reverie chin on his hand, like 'Rodin's Thinker' ruminating, one presumes, on ideas like using a borrowed American satellite to transmit educational content to 2400 villages in India's backward regions or a spectacular scheme of building agricultural complexes serviced by atomic power and desalinated sea water.

Fifty years after his death those dreams are taking us to the moon.

doi: $10.18520 / \mathrm{cs} / \mathrm{v} 118 / \mathrm{i} / 1190$ 